\title{
ECO-PESANTREN AS A BASIC FORMING OF ENVIRONMENTAL MORAL AND THEOLOGY
}

\author{
Herdis Herdiansyah \\ School of Environmental Science, Universitas Indonesia \\ herdis@ui.ac.id \\ Hadid Sukmana \\ School of Environmental Science, Universitas Indonesia \\ hadidsukmana@gmail.com
}

\section{Ratih Lestarini}

Faculty of Law, Universitas Indonesia

ratihlestarini@yahoo.com

\section{Abstract}

The rising of education with an environmentally friendly approach becomes one of the focuses on implementing sustainable growth of social life. This principle includes an attempt to develop the ecologically friendly pesantren. Along the time, pesantren is identified as a religion and social center. Meanwhile, its surrounding environment has not become the primary priority. This paper sought to analyze the activity of community service related to initiating the perspective change of pesantren. The study implies that pesantren not only an education institute practicing educational activity, but also become an agent of change for creating a better social life and society around, and further, to perform the environmentally friendly pesantren. The research used the literature review approach to propose the Eco-Pesantren strategy, the benefits and social-economic impact for pesantren and the greater community. Moreover, the Eco-Pesantren concept becomes the basis and good characteristic learning with concern for the environment. Furthermore, environmental theology brings Eco-Pesantren on the profound philosophy of eco-ethical perspectives. 


\section{Abstrak}

Meningkatnya sistem pendidikan dengan pendekatan yang ramah lingkungan menjadi salah satu fokus pada penerapan pertumbuhan kehidupan sosial yang berkelanjutan. Prinsip ini termasuk upaya untuk mengembangkan pesantren yang ramah lingkungan. Seiring waktu, pesantren diidentifikasi sebagai salah satu pendidikan agama dan pusat sosial. Sementara itu, lingkungan sekitarnya belum menjadi prioritas utama. Tulisan ini berusaha menganalisis aktivitas pengabdian masyarakat terkait dengan memulai perubahan perspektif pesantren. Studi ini menyiratkan bahwa pesantren bukan hanya lembaga pendidikan yang mempraktikkan kegiatan pendidikan, tetapi juga menjadi agen perubahan untuk menciptakan kehidupan sosial yang lebih baik dan masyarakat sekitar, dan lebih jauh lagi, untuk melakukan pesantren yang ramah lingkungan. Penelitian ini menggunakan pendekatan tinjauan pustaka untuk mengusulkan strategi EcoPesantren, manfaat dan dampak sosial-ekonomi bagi pesantren dan komunitas yang lebih besar. Selain itu, konsep Eco-Pesantren menjadi dasar dan pembelajaran karakteristik yang baik dengan kepedulian terhadap lingkungan. Lebih lanjut, teologi lingkungan membawa Eco-Pesantren pada filosofi-filosofi ekologi-etika yang mendalam.

Keywords: Cooperation, Education, Eco-Pesantren, Social Empowerment, Theology.

\section{A. Introduction}

Environmental damage is currently heavily influenced by modern paradigms that tend to be anthropocentric. The rise of anthropocentric paradigms to nature and the dualism of human relationships with nature causes enormous environmental damage. When man ceases to view himself as a living being given a mandate by Allah SWT to preserve the environment and no longer regard the environment as a precious deposit, then it will drive environmental crisis.An example is when a Muslim forgets that Muslims are forbidden to harm others, and environmental degradation is an act that can damage and harm the current generation and future generation. A famous philosopher, Rene Descartes, contributed a lot to the development of dualism which assumes that mind and body are unity. The concept of dualism is criticised by some scientists such as Val Plumwood, the concept of dualism is the cause of destructive behavior towards natures. The idea leads to the failure of the human mindset about nature. Nature is regarded only as a satisfaction of the human ego and is entitled to be exploited according to the will of human. The damages caused by the anthropocentric paradigm and dualism are very worrying. The concept of dualism makes people far from nature. The separation between humans and environment has proven to be a primary cause of environmental destruction. 
The development of modern science also affects the occurrence of the environmental crisis. Modern science is considered to have a concept that tends to materialism and secularism so that we see nature is merely a quantitative value. Economic development is one such example. Western economics is a notion that exploits the natural environment and prioritises intergenerational prosperity and justice as its main factor. Nature seems to have lost its beauty. The beauty of nature is measured only by the material alone. How much of that nature can make a profit for humans? By re-establishing the great value of science and nature, the ongoing crisis can be stopped. Understandings that tend to make people treat nature with arbitrary should be eliminated immediately. The various religions in the world have the same knowledge that the exploitation of nature for profit is an immoral act. All religious people must obey the moral rule of nature.

Therefore, an understanding of nature or the environment based on spiritual reflection needs to be presented. In Islam, environmental theology is based on the study of the Qur'an and the Sunnah of Prophet Muhammad SAW. In the Qur'an and the hadith of the Prophet, many counsels are given to humans to preserve nature. When there was a prophetic battle, the Prophet Muhammad forbade the destruction of trees in the battle. Therefore, environmental theology is one solution that can be developed to seek answers to environmental problems that occur at this time. The concept of environmental theology makes people realize that there is an important relationship between nature, human, and the creator. Religion and ecology are the fields of academic study, but since their inception, everything has not been purely theoretical. It consists of two interests: the scientific interest and theological-ethical concern. In Indonesia, religious leaders have shown following reports and the development of environmental sciences such as environmental Fiqh. Besides, the challenges are more severe because the awareness of environment is decreasing among the people as well as apathetic and indifferent to the environment. Usually, human will be aware after they have felt high impact due to the damage to the environment. Therefore, the action to maintain and sustain the nature for the public good is a responsibility for together and cannot be bargained.

Pesantren is the Indonesian term of Islamic boarding school. It is one of the Islamic education types in Indonesia which traditionally studied, understood, explored, appreciated, and practice the Islamic teaching as a guideline to behave in every day. Islam is not just a set of belief, but rather a 
set of an idea, ethic, and ideals in all aspects of human life. Pesantren is a traditional Islamic education to explore and practice the Islamic religion in everyday life. According to Mastuhu ${ }^{1}$, Pesantren tried to create and develop a Muslim personality, God, noble morality, beneficial to society or submissive in the community by becoming a servant or public servant as well as an Apostle, that becomes a servant of society as the personality of the Prophet Muhammad. Meanwhile, according to Kull2 , Pesantren had an orientation of traditionalists and Kyai as a symbol of the public figure in changing the attitude and environment sustainability.

Pesantren as Islamic education center based on its history and vast existence could be understood having significant enough effect on surrounding community. During its existence, Pesantren gave big contribution as educational institutions, religious broadcaster, and socio-religious movement. Pondok Pesantren that teaches about religion and values of simplicity with polite, egalitarian, and without violence, will make the student more diligent ${ }^{3}$ and have high motivation to learn. The parents of student want their children to have high knowledge with good moral ${ }^{4}$. Pesantren is believed as an alternative to solve various educational problems recently. Pesantren as religious education institution could be the social initiator in surrounding community since based on research Siregar ${ }^{5}$ religious education institution could create value, norm, and attitude adopted by the student. Moreover, in the previous research, Llewellyn ${ }^{6}$ stated that environmental conservation with religious basis was more effective because the spiritualistic basis of environment will be rewarded in the future.

${ }^{1}$ Mastuhu, Dinamika Sistem Pendidikan Pesantren: Suatu Kajian Tentang Unsur Dan Nilai Sistem Pendidikan Pesantren (INIS, 1994).

${ }^{2}$ Ann Kull, "Gender Awareness in Islamic Education: The Pioneering Case of Indonesia in a Comparison with Pakistan," Studia Islamika, Vol. 19, no. 3 (2014).

${ }^{3}$ Shagufta Perveen and S Farhana Kazmi, "Personality Dynamics of Boarders and Day Scholars Who Belong to Madrassah and Public School," Academic Research International, Vol. 1, no. 1 (2011), p. 157.

${ }^{4}$ Herdis Herdiansyah, Trisasono Jokopitoyo, and Ahmad Munir, "Environmental Awareness to Realizing Green Islamic Boarding School (Eco-Pesantren) in Indonesia," Vol. 30 (IOP Conference Series: Earth and Environmental Science, IOP Publishing, 2016), 01, 2017.

${ }^{5}$ Ferry Muhammadsyah Siregar, "Religious Leader and Charismatic Leadership in Indonesia: The Role of Kyai in Pesantren in Java," Jurnal Kawistara, Vol. 3, no. 2 (2013).

${ }^{6}$ Othman A Llewellyn, "The Basis for a Discipline of Islamic Environmental Law," Islam and Ecology, 2003, p. 185-247. 
Pesantren in Indonesia categorized as the modern and traditional educational institutions. A modern Pesantren usually follows a national school curriculum. On the other hand, traditional Pesantren focuses more exclusively on religious subjects. Majority of Pesantren in Indonesia are traditional and therefore independent of formal government control ${ }^{7}$. Pesantren is a breakthrough in the world of Islamic education in Indonesia because it separates between men and women. Pesantren educates women to get gender justice, leadership material for women also given in Pesantren ${ }^{8}$.Education is the key to the preservation of the new generation's religious and cultural identity while establishing a sense of pride. The role of Islamic education in this modern era should be to teach the new generation that globalization is a reality ${ }^{9}$. Pesantren can be assumed as a castle of Islamic knowledge as well as the main place to create Muslim individuals and Islamic teacher. By focussing on classical Islamic sciences, Pesantren gives teaching subjects such as Qur'an, Hadith (collection of sayings and deeds of Prophet Muhammad), Fiqh (jurisprudence), Arabic grammar, Tasawuf (mysticism), and Arabic science.

Hefner ${ }^{10}$ stated that most of the pupils and their parents would happily prefer to an education that combines Muslim learning with knowledge of the national language, mathematics, science, and even English. The main reason that government and government-sanctioned schools have achieved some success, in fact, is that Southeast Asian, even those firmly committed to Islamic value, also want the more useful knowledge, leading to being succeeded in examination, credentials and marketable skills. The relationship between Pesantren and community was built through psychological and ideological cohesion. Psychological cohesion happened because Pesantren was born from the rural religious communities. Meanwhile, it is also called ideological because Pesantren is a place to defend religious belief. Pesantren which located in rural areas, in general, is weak in its economic situation. Now, Pesantren has tried to exploit its potential by the human resource and school management

${ }^{7}$ Charlene Tan, Islamic Education and Indoctrination: The Case in Indonesia (Routledge, 2012).

${ }^{8}$ Eka Srimulyani, "Muslim Women and Education in Indonesia: The Pondok Pesantren Experience," Asia Pacific Journal of Education, Vol. 27, no. 1 (2007), p. 85-99.

${ }^{9}$ Kalthoum Alkandri, "The Transformation and Challenges of Islamic Education in a Globalized," International Education, Vol. 44, no. 1 (2014), p. 91.

${ }^{10}$ Robert W Hefner, Making Modern Muslims: The Politics of Islamic Education in Southeast Asia (University of Hawaii Press, 2009). 
developments. This progress was developed continually with different themes and patterns of Pesantren. As an educational institution that teaches religious value, Pesantren also has programs of social and economic development such as through Eco-Pesantren. The sustainability of Pesantren program has been moved by initiation and motivation from the Kyai in protecting the environment. This is all parts of da'wah (pray) to the people.

However, according to Sirry ${ }^{11}$, we cannot ignore the dynamic development within the inner circle of the Pesantren itself. That resulted in the Pesantren's ability to respond in constructive ways to external challenges such as the introduction of the Westernized school system at the beginning of the century is the one firm autonomy which gives the Pesantren enough flexibility to pioneer new educational concepts. It was culturally playing complementary roles with ideological awareness to provide a stable base for the fundamental transformation needed by the nation shortly. It correlates with the human development of human ecology approach will mix Pesantren as the right united social-cultural, as well as the model that emphasised self-help. The Kyai built Pesantren building by his own money or the people fund. The progress of Pesantren that reflects the values of its community in obtaining religious and environmentally goals could be best developed in Pesantren circumstance.

The realization of environmentally friendly Pesantren can be done when we have to understand the typology of Pesantren as an educational institution which differs from the other formal educational institutions. Pesantren was initially centered on learning and broadcasting the value of Islam. However, on its progress, this institution develops its coverage for accelerating not only the vertical mobility (religious matters) but also horizontal mobility (social and environmental consciousness). The Kyai on Pesantren teaches religion, value system, real charity, and environmental overview to his students. Keeping the nature is an obligation for everyone ${ }^{12}$. Therefore, as a part of society, we need to save the nature because nature is a unity which complementary and mutually supportive. We are not permitted to abandon the land, and we also

${ }^{11}$ Mun'im Sirry, "The Public Expression of Traditional Islam: The Pesantren and Civil Society in Post-Suharto Indonesia," The Muslim World, Vol. 100, no. 1 (2010), p. 60-77.

${ }^{12}$ Syamsul Bahri, "Pesantren And The Development Of Living Environment: The Study Concept Of Eco-Pesantren In Pondok Pesantren An-Nur Ha Rambigundam Jember," International Journal of Management and Administrative Sciences, Vol. 5, no. 10 (2018), p. $43-54$. 
have to maintain and care the environment. The consciousness become a basis of people serving in realizing the development of Eco-Pesantren as a base of environmentally moral character building.

Eco-Pesantren program is a model of environmental education in Pesantren to preserve the nature and increases the awareness of health. In safeguarding the Pesantren circumstance, it can recycle used goods, make composting, and avoid environmental pollution by water treatment. Meanwhile, regarding health, Pesantren can prepare herbal pharmacy by planting the medicinal plants (in Indonesia called TOGA/Tanaman Obat Keluarga) which all are managed by the students or female students and controlled by the school, like in Adiwiyata School and Eco-Campus.

\section{B. Conceptual Framework and Assumption}

Eco-Pesantren program is a model of environmental education in Pesantren boarding school that still develop in many places of Pesantren basis in Indonesia. On its current progress, many agencies and environmental programs direct and support their actions for environmental matters such as the go-green program. This is new program since the old type of Pesantren which circled their environment to just only religious study and doctrine. Concerning with the degradation of environment situation, created a new perspective of Pesantren that be linked in an environmental perspective. Finally, a model called Eco-Pesantren was introduced through this program. It is beneficial to form the Pesantren cadres who have conservation consciousness. Moreover, this program is developing environmentally friendly moral characteristic to the Pesantren students through the program of Eco-Pesantren.

Since the positive nature of eco-friendly behavior towards nature and others impacts both current and future, eco-acting can be viewed as moral behavior $^{13}$. As compiled by the study, many people agree with nature to have intrinsic value, and humans have a moral obligation and an obligation

${ }^{13}$ Aldo Leopold, A Sand County Almanac: And Sketches Here and There (Outdoor Essays \& Reflections) (Oxford University Press, 1989); Thomas A Heberlein, "The Land Ethic Realized: Some Social Psychological Explanations for Changing Environmental Attitudes," Journal of Social Issues, Vol. 28, no. 4 (1972), p. 79-87; John Thøgersen, "Recycling and Morality: A Critical Review of the Literature," Environment and Behavior, Vol. 28, no. 4 (1996), p. 536-58. 
to animals, plants and non-living ${ }^{14}$, and moral responsibility for coping with climate change ${ }^{15}$. The choice to engage in eco-friendly behavior on the desire to do moral things ${ }^{16}$. One of the pillars on which people base their self-image is their actions ${ }^{17}$. How morally people perceive their behavior can affect a person's moral self-image, the central part of a broader positive self-concept ${ }^{18}$. When they engage in the good moral behaviour, people see themselves as good and clean people as well as good people.

Research shows the existence of behaviours in eco-friendly behaviour that can affect each other how to see themselves. Green acting can lead to a more environmentally-friendly identity ${ }^{19}$ because when people behave in an environmentally friendly way, they tend to see themselves as stronger as the environment-friendly people. If eco-friendly behaviour as a manifestation of morality, as we think above, the following will be able to produce a positive self-image overall. Indeed, eco-friendly behaviour has encouraged people

${ }^{14}$ Anthony A Leiserowitz, Robert W Kates, and Thomas M Parris, "Do Global Attitudes and Behaviors Support Sustainable Development?" Environment: Science and Policy for Sustainable Development, Vol. 47, no. 9 (2005), p. 22-38.

${ }^{15}$ Irene Lorenzoni, Sophie Nicholson-Cole, and Lorraine Whitmarsh, "Barriers Perceived to Engaging with Climate Change among the UK Public and Their Policy Implications," Global Environmental Change, Vol. 17, no. 3-4 (2007), p. 445- 59.

${ }^{16}$ Shalom H Schwartz, "Normative Influences on Altruism1," in Advances in Experimental Social Psychology, Vol. 10 (Elsevier, 1977), p. 221-79; Shalom H Schwartz and Judith A Howard, "A Normative Decision-Making Model of Altruism," Altruism and Helping Behavior, 1981, p. 189-211; Siegwart Lindenberg and Linda Steg, "Normative, Gain and Hedonic Goal Frames Guiding Environmental Behavior," Journal of Social Issues, Vol. 63, no. 1 (2007), p. 117-37.

${ }^{17}$ Daryl J Bem, "Self-Perception: An Alternative Interpretation of Cognitive Dissonance Phenomena.," Psychological Review, Vol. 74, no. 3 (1967), p. 183; Daryl J Bem, "Self-Perception Theory1," in Advances in Experimental Social Psychology, Vol. 6 (Elsevier, 1972), p. 1-62.

${ }^{18}$ Karl Aquino and II Reed, “The Self-Importance of Moral Identity.”, Journal of Personality and Social Psychology, Vol. 83, no. 6 (2002), p. 1423; David Dunning, "Self-image Motives and Consumer Behavior: How Sacrosanct Self-beliefs Sway Preferences in the Marketplace," Journal of Consumer Psychology, Vol. 17, no. 4 (2007), p. 237-49; Sonya Sachdeva, Rumen Iliev, and Douglas L Medin, "Sinning Saints and Saintly Sinners: The Paradox of Moral Self-Regulation,” Psychological Science, Vol. 20, no. 4 (2009), p. 523-28.

${ }^{19}$ Gert Cornelissen et al., "Positive Cueing: Promoting Sustainable Consumer Behavior by Cueing Common Environmental Behaviors as Environmental," International Journal of Research in Marketing, Vol. 25, no. 1 (2008), p. 46-55; Ellen Van der Werff, Linda Steg, and Kees Keizer, "Follow the Signal: When Past pro-Environmental Actions Signal Who You Are," Journal of Environmental Psychology, Vol. 40 (2014), p. 273-82. 
to see themselves in a more general positive light ${ }^{20}$. Besides, many people's thoughts about themselves are important determinants of their good feelings ${ }^{21}$. If you understand one's actions to be environmentally friendly to a positive self-image, this self-image can produce positive emotions.

As suggested by $\mathrm{Bem}^{22}$, the circumstances under which it may occur affect the behaviour itself is interpreted. An important attitude in the theoretical considerations of morality is a decision classified as morally only if the person who makes it a responsible agent, choosing intentional and willing action when he can do the other ${ }^{23}$.After this punishment, the same eco-friendly action will be interpreted as morally good behaviour when the person actively chooses (on command) to pursue it. Furthermore, when people voluntarily wish to engage in certain actions, they tend to influence choices to experience internally and not external causes ${ }^{24}$. In short, choose to do what you want - not just for others, but also for yourself ${ }^{25}$.

The assumption is that Pesantren has not only dwelled on religiousbased curriculum (regional-based curriculum) but also on society curriculum matters (society-based curriculum). Pesantren is not framed as a purely religious institution but should be the social institutions that have continually respond to the problems surrounding communities and including environmental awareness. Besides, the efforts of nature conservation will be very helpful in developing the understanding and public awareness of environmental issues.

${ }^{20}$ Danny Taufik, Jan Willem Bolderdijk, and Linda Steg, "Acting Green Elicits a Literal Warm Glow," Nature Climate Change, Vol. 5, no. 1 (2015), p. 37.

${ }^{21}$ Shelley E Taylor and Jonathon D Brown, "Illusion and Well-Being: A Social Psychological Perspective on Mental Health.,” Psychological Bulletin, Vol. 103, no. 2 (1988): 193; Roy F Baumeister, "Understanding the Inner Nature of Low Self-Esteem: Uncertain, Fragile, Protective, and Conflicted," in Self-Esteem (Springer, 1993), p. 201-18.

${ }^{22}$ Bem, "Self-Perception Theory1."

${ }^{23}$ Heberlein, "The Land Ethic Realized: Some Social Psychological Explanations for Changing Environmental Attitudes.”

${ }^{24}$ Edward L Deci and Richard M Ryan, "The" What" and" Why" of Goal Pursuits: Human Needs and the Self-Determination of Behavior," Psychological Inquiry, Vol. 11, no. 4 (2000), p. 227-68; Richard M Ryan and Edward L Deci, "Self-Determination Theory and the Facilitation of Intrinsic Motivation, Social Development, and Well-Being.", American Psychologist, Vol.55, no. 1 (2000), p. 68; Van der Werff, Steg, and Keizer, "Follow the Signal: When Past pro-Environmental Actions Signal Who You Are."

${ }^{25}$ Ronit Bodner and Drazen Prelec, "Self-Signaling and Diagnostic Utility in Everyday Decision Making,” The Psychology of Economic Decisions, Vol. 1 (2003), p. 105-26. 
The program is developed by the method of cooperation among stakeholders. The methods are not only socialization but also the involvement and participation of Pesantren community together with related institutions. The steps in community engagement begin with field research problem step related with economic, social, and culture of Pesantren as well as environmental management. The next step is knowledge sharing by transfer of knowledge such as how implemented Pesantren concepts which is green like Pesantren garbage bank management, clean and healthy campaign, land exploration for productive and medical plants, and green curriculum program.

The programs are arranged together with the stakeholders from Pesantren and the people around. The objective of socialization program is gradually initiating Pesantren as a partner of green Pesantren. This program becomes urgent since it's not only arranging green Pesantren by changing un-care for environment attitude of the people around but also becoming a motivator of environmental care to the people. It means that Eco-Pesantren program wants to change Pesantren as the not only basis of education, moral, and religion, but also becomes the initiator of people's care around Pesantren and the broader community.

Wrong management caused the failure of community empowerment programs at Pesantren during this time due to making the people as an object that can be controlled by the subject. In fact, such a model approach faces more failures. Through a community approach as a subject, Pesantren was prosecuted for sharing the value and knowledge of what should be developed and improved for the better achievement.

\section{Eco-Pesantren from Environmental Moral Perspective}

Islam as a religion which concerns about environment shown with teachings such as prohibition about not exceeding the requirement of a decent standard and should reconsider about the sustainability of life aspect, preservation of nature and ecosystem equilibrium. The involvement of EcoPesantren, surrounding communities, and relevant stakeholders can assist Pesantren in realizing Pesantrenthat environmentally friendly. Pesantren can be the agents of change in creating a sustainable environment for the process of development and establishment of personal character in understanding the religion (Islam) to learn, understanding, exploring, appreciating and 
practising the teachings of Islam as normal behaviour as a manifestation of moral values.

Environmental development efforts can be made through two kinds of approaches. First, the project approach and second, motivation approaches. At the same time, it can be integrated. The second method, (motivation) although require relatively long time, will cause more positive impact because the target gradually is willing to change attitudes and behaviour persuasively. Behavior and indifference to environmental problems will turn out to be an evolving dynamic attitude that will culminate in the development of environmental stability.

This motivational approach can be carried out in the pattern of Pesantren education. Awareness of environmental balance that arises from a basic understanding of its problems and the implications for ukhrawi welfare and worldly can be instilled and developed through education in this environment.

Deuraseh study stated that Islamic value and attitude in facing environment is clear, however, since low educational approach, this issue is not yet becoming Islamic people priority ${ }^{26}$. It means that besides value and norm, environmental education is Islamic ethic that should be implemented continually.

Malone and Paul in their study declared that the learning environment has three dimensions. Learning to support the knowledge and understanding of the environment ${ }^{27}$. Learning to be directed towards awareness and action on the environment, as well as learning to encourage interaction and experience in the environment.

Building societies that aware of the environment are not sufficient for conventional education. Through formal, environmental education has started relatively long. In 1986 the Environment and Population Education were incorporated into the formal education with the establishment of lessons, namely Population and Environment Education (PKLH). At the

${ }^{26}$ Nurdeng Deuraseh, Maintaining a Healthy Environment: An Islamic Ethical Approach, Vol. 8, 2009.

${ }^{27}$ Karen Malone and Paul Tranter, “"'Children's Environmental Learning and the Use, Design and Management of Schoolgrounds," Children Youth and Environments, Vol. 13, no. 2 (2003), p. 87-137. 
same time, the Ministry of Education has also begun to integrate PKLH into all subjects. ${ }^{28}$

It is important to note that the environmental code of conduct is also reflected by the fundamental beliefs of Islam such as monotheism, the caliph, and the living after death. Where man as caliph responsible for complying with the rules of Allah and protect his creations on earth including the environment ${ }^{29}$.

Pesantren with its function and role as mentioned above is filled with a variety of educational activities and community service. To be empowered in the coaching environment, there needs to be an approach that does not disrupt the pattern of its main task, especially on the identity bears. The first step that needs to be done is the introduction of a variety of environmental issues and its influence in all aspects of life. Then an effort to foster religious insight similarities related to the environment that can motivate schools to find alternative solutions according to their potential independently.

Empowerment Pesantren with some of the activities expected to be one of the corners of environmentally friendly activities. Kyai, Ustadz and Santri can bring a positive feel in instilling and public awareness in environmental issues. In realizing environmentally friendly Pesantren, a policy required from The Kyai who can support environmental education activities conducted by the resident cottage.

Oriented policy environment is an important aspect in supporting the realization of the development programs and activities of Eco-Pesantren. Thus, Eco-Pesantren program will be able to accommodate, among others, curriculum and environmental activities in the Pesantren and the surrounding neighbourhood as well.

The problem is caused among other schools as an educational institution, in general, is a complex built without careful planning. This means that the tendency of established building structure made according to the needs. This was done because of the schools more emphasis on self-reliance and simplicity in operation, wherein the development of the number of

${ }^{28}$ Maghfur Ahmad, "Pendidikan Lingkungan Hidup Dan Masa Depan Ekologi Manusia," Vol. 8, 2010, p. 57-71.

${ }^{29}$ Mumtaz Akhter, Tanveer Iqbal, and Mubashra Khalid, "Islamic Educational Approach to Environment Protection: A Strategic Approach for Secure and Peaceful World," International Journal of Business and Social Science, Vol. 1, no. 3 (2010). 
students is increasing and coming from outside the area. It certainly needs a place to stay during studying from Kyai and later appeared buildings to shelter they built the students by making use of land belonging to Kyai commonly called the Pondok. Along with the times, now many Pesantren that show progress if viewed regarding building the facility layout and construction of its buildings with magnificent and charmingly arranged according to their plan.

But in this case, not all schools can innovate as shown by several schools in the field of physical progress. This is due to the limited ability to provide an area for expansion and limited funds. Thus, we can find some schools when viewed regarding the building seem irregular and improvise. For example, a narrow room to accommodate the number of the students were quite a lot so crowded that exceeds the capacity. The availability of clean water is insufficient for bathing, drinking, cooking and washing and disposal of human waste, solid and liquid wastes.

Adams et al. stated that schools, especially in rural areas, often lack potable water and sanitation facilities and the alternative to hand washing, even though such facilities exist but often inadequate regarding quality and quantity. ${ }^{30}$ This situation will certainly affect the environmental health aspects of Pesantren community itself, such as the health aspects related to the environment. Because in basically, public health in this community has a close relationship with Pesantren environment.

Efforts to empower students to environmental healthiness starts by involving the students in the process of preservation and management of clean water, clean room residence, maintaining the cleanliness of public toilets, waste management and participation of wider environmental hygiene not only in schools but broader scope in the surrounding community.

Thus, the active role of the boarding school in the health sector can be realized in the Pesantren and surrounding communities so that the impression is a seedy Pesantren will vanish along with hygiene awareness of the students as well as make Santri as the "agent of change" of environmental health. And more important mission "PHBS (Perilaku Hidup Bersih dan Sehat)" or Clean and Healthy Behaviorlaunched by the government can be achieved to improve public health through community empowerment, including the private

${ }^{30}$ John Adams et al., Water, Sanitation and Hygiene Standards for Schools in Low-Cost Settings (World Health Organization, 2009). 
sector and civil society; protect public health by ensuring the availability of health efforts plenary, equitable, and fair quality; ensuring the availability and equitable distribution of health resources.

Humans must learn about nature to find God "Allah" and use it for the benefit of humanity. Pesantren as religious education institutions would be closer to the values of Islam as sources of conception and motivation. The Kyai in the teaching of religion and the values of simplicity and independently, without violence, making The Santri more active in learning so that the Kyai became the foundation of life for the people. Thus, community empowerment program Eco Pesantren as Environmentally Friendly Morale Character Building Base can easily be implemented in Pesantren schools and communities around the schools as well.

Development of environmentally friendly Pesantren with cooperation across stakeholder can be realized because of the principles and rules of the development of environmentally-friendly education. Pesantren as the basis of personality and character formation of Islamic morality synergy with the environment demanded not only understand the religious science and science alone but also become role models for the human future pro and care for the environment.

\section{Eco-Pesantren from Environmental Theology Perspective}

It is evident that once again, religion has a critical role in solving environmental problems. Nasr considers that the environmental crisis is a spiritual crisis that exists in humans ${ }^{31}$. The environmental crisis is a sign that there is a crisis in ourselves. This is due to the existence of modern secular sciences which eliminates many aspects of ethics, social and moral. The ecology taught by the Prophet Muhammad is the ecology that is done to prevent the occurrence of a disaster.

Bailey, a very liberal Christian with a Masonic background is one of the earliest pioneers of eco-theology, the religious thought, and action of the relationship between human and nature. Bailey also wrote poetry and philosophy. One of the most famous and important is his treatise in 1915 on the Holy Earth. Here Bailey argued firmly to apply the stewardship ethics in

${ }^{31}$ Seyyed Hossein Nasr, "Islam and the Environmental Crisis," Islamic Quarterly, Vol. 34, no. 4 (1990), p. 217. 
caring for the Earth ${ }^{32}$. The book also includes some arguments suggesting the radically intrinsic value of non-human beings at the time ${ }^{33}$. A recent research project revealed that there were more eco theological advocates in the first half of the 20th century than had previously been recorded ${ }^{34}$.

In a recent study, the approach adopted by exploiting the fundamental eco-ethical thinking in Islam, namely the theological and Quranic principles and the example of the Prophet Muhammad (Sunnah) oriented towards sociopolitical and ecological reform. It relies on a tradition of liberation in Islamic thought which argues that Muslims need to understand Islamic references, i.e. to assess their sources, instruments and methodologies (interpretive, legal, ethical) and apply them to meet the challenges of our times.

This is called history in history where spirituality is not fun but lifeaffirming, an approach that makes it clearly that "spiritual battles are won or lost in the plains of the world". Muslim ecologists extend the discourse of Islamic liberation to ecological questions by building alternative environmental imagery based on God's sovereignty and guardianship responsible for humanity. The eco-Islamic scholars, since the late 1960s, have applied the central ethical precepts detailed in the Qur'an and Sunnah to establish Islamic theocentric ecosystems ${ }^{35}$. The proposed environmental ethics centers on five fundamental principles that lie behind the fundamental aspects of the message of the Islamic environment.

The eco-ethical principles that determine the relationship between creator, human and creation are triggered by a system of legal, legal and institutional methods - Shariah - which seeks to secure the universal common good and the welfare of creation. Shariah also aims to improve human relationships with science, education, ethics and community, create moral and just conduct in society and reduce all present dangers. Thus, Muslims are meant to actualize the precepts of their faith by applying Shariah, a roadmap to navigate life on earth. Thus, Shariah promotes the norms that apply to

${ }^{32}$ Liberty Hyde Bailey, "The Holy Earth (1915)," Reprint. New York: New York State College of Agriculture and Life Sciences, 1980.

${ }^{33}$ Ben A Minteer, The Landscape of Reform: Civic Pragmatism and Environmental Thought in America (MIT Press, 2006).

${ }^{34}$ Panu Pihkala, "Rediscovery of Early Twentieth-Century Ecotheology," Open Theology, Vol. 2, no. 1 (2016).

${ }^{35}$ Ibid. 
all people. Even if there is no law enforcement, every Muslim is aware of his responsibility to live according to his teachings because he will be called to account for the weight of a good atom or evil done on this earth.

The ethics of ecological justice built consists of convincing ecological teachings and a dynamic legal system that promotes fair, responsible and respectful interaction between humans and nature. The religious duties of humanity in the Islamic worldview extend to the environment since caring for the earth are acts that can earn rewards and incur punishment. Thus, Muslims should "not only feed the poor but also avoid polluting the flowing water. It is pleasing in the eyes of God not only to be kind to the parents but also to plant trees and treat animals gently and well" ${ }^{\prime 3}$. In the diverse context of Muslim societies, Foltz points out in his publication, Environmentalism in the Muslim world, that a successful indigenous movement in the Muslim world demands compatibility demonstrated by Islamic norms ${ }^{37}$.

The environmental theology in Islam focuses on the principles of ethics and its concepts, such as the discussion of the unity of God (tawheed), the leader (khalifah) and the balance (Mizan) that will shape the theology's view of the Islamic environment itself. Islamic environmental theology exemplifies that humans are not allowed to consume natural resources in excess if not required.

This is very much at odds with the evolving modern paradigm of such an anthropocentric paradigm. Environmental ethics on anthropocentric is based on human welfare at the expense of other life so that human as if entitled to consume nature excessively.

Environmental and ecological awareness is the main thing in Islam because Islam teaches its people to see nature as a holy book equivalent to the holy book of the Qur'an. By understanding nature, Muslims will appreciate the value of nature and its spiritual meaning and bring it closer to their creator. Besides, Islam teaches its people to use nature according to the law outlined in the Qur'an. This means that God created nature to meet human needs, but at the same time human beings have a moral duty to defend and protect nature as well.

\footnotetext{
${ }^{36}$ Nasr, "Islam and the Environmental Crisis."

${ }^{37}$ Richard Foltz, "Environmentalism in the Muslim World," 2005.
} 
Seyyed Hossein Nasr one of Islamic thinkers has a concept of the environment. The idea of the environment departs from the mindset that the environmental crisis cannot only be understood through the eyes of science alone but must be recognized and understood from the spiritual and religious side of depth. Modern society needs to seek theological value in the environment because the environmental crisis is not merely a technological problem, but the spiritual drought that is plaguing modern humans $\mathrm{s}^{38}$.

In the concept of Islamic environmental theology, there is the concept of fitrah. Fitrah means pure; meaning is something that describes the nature of the purity of human creation. Consciously humans can choose natural patterns when they are created. Fitrah is a natural state owned by humans where the condition is considered in harmony with nature. If a human followed his nature as a creature of God, then balance and harmonization in nature will be created.

The concept that exists in Islam is to believe in the unity of God, commonly called Tawheed. The universality is depicted in the unity of human and nature. The paradigm that developed like the dualism paradigm between human and nature is a paradigm that is foreign to Islam because Islam does not recognise the existence of dualism between nature and human. The concept of dualism that developed in the West is very much in contradiction with the concept of Deity which is believed by Muslims.

From this monotheism then arose the concept of caliphate and Amanah. This means that human as khalifah does not mean human free from God but must be put the greater responsibility to God for all activities of science and technology. Islam describes humans as khalifah namely those who are obliged to manage and regulate the environment and thus have an ethical responsibility to address the dangers committed to environmental entities.

Nature is a trust given by God to keep us, and we preserve it well. Human is given freedom by God to take as much benefit from nature but not to control nature but to protect nature. Human must be responsible for any deviations and misuse of the trust.

In Islam, the Qur'an and prophetic treatises provide law and ethics for environmental practice. Sharia or Islamic religious law deals with all aspects of Muslim life including environmental practices. In other words, the Sharia

\footnotetext{
${ }^{38}$ Nasr, "Islam and the Environmental Crisis."
} 
provides the legal structure and ethical norms in which a Muslim country can make decisions about environmental issues.

Fiqh or Islamic law can also protect the environment. However, most Muslim countries adopt only a few of the Shariah. Therefore, Nasr advised them to bring out the Shariah ruling on the preservation of nature and affection for animals and plants. Nasr believes that environmental laws will be imbued with religious meaning and thus will address environmental concerns in Islamic countries more efficiently.

Studies among Muslim students at tertiary institutions in Malaysia show that $43.4 \%$ of students contribute little to the environment and they are not committed to environmental conservation ${ }^{39}$. Nasr explained that ignorance among Muslims was caused by the onslaught of Western civilization since the 18 th century and the destruction of most Islamizers ${ }^{40}$. Although Islam continues to grow, the level of faith among Muslims has not been too deep to confront western cultural, scientific and technological ideas and practices.

When Muslims embrace the values of the Islamic environment as reflected in their norms and behaviour, they will support and practice management for the environment and natural resources. This can be seen as an approach to strengthening Islamic teachings among Muslims and developing guiding principles to respect the environment. Another approach can be made by widening the awareness of Shariah teachings about the ethical treatment of the natural environment and applying it to the principles of Shariah.

Environmental education and awareness are vital to mobilize community participation in environmental improvement activities. Environmental education at the primary, secondary and tertiary levels can lead to changes in positive behaviour toward energy conservation and waste reduction and respect for other living beings.

Effective long-term environmental management will require public information and support. There is a need to raise environmental awareness at all levels of society, including school children, private business sectors, nongovernmental organizations and government officials at both management

${ }^{39}$ Mohd Nor Mamat and Fattawi Mokhtar, "Environmental Attitude Profile among Muslim Students of Environmental Course in Malaysia," Procedia-Social and Behavioral Sciences, Vol. 42 (2012), p. 92-99.

${ }^{40}$ Seyyed Hossein Nasr, "Islam and the Problem of Modern Science," Muslim Education Quarterly, Vol. 5, no. 4 (1988), p. 35-44. 
and administrative levels. Education makes people understand the role and position in society. This role will determine the attitude of human to his place of residence that is nature. Education not only shapes our attitude toward the environment but also enhances our ethics to the environment. As ethics rises, there will be a sense of responsibility in caring for the environment and the natural environment.

Responsibility needs to be done to maintain natural stability. This attitude is also reflected in a concept of education taught in a religious, educational institution in the form of boarding schools. Pesantren has a significant role in the management and conservation of the environment. Pesantren education seeks to improve the attitude and concern of santri to the environment. Besides, Pesantren also instills the mindset to be able to preserve and preserve the environment.

Pesantren education is focused on improving and developing human skills in solving the environmental crisis. Environmental education in Pesantren educational institutions is aimed at creating a sense of caring and responsibility for conserving, preserving and maintaining the environment. If the system is applied in Pesantren educational institutions, it will create the concept of Eco-Pesantren.

Eco-Pesantren consists of two words that both have different meanings. Eco comes from the word Ecology or Ecosystem which is the understanding of the environment or nature around. Pesantren is an Islamic educational institution in Indonesia. This educational institution teaches the religious sciences in the form of learning of classical Islamic books or modern books. Eco-Pesantren indirectly can be said as a form of eco-theology. Ecotheology is a belief that combines the ideology and actions of religion and the environment.

Eco-Pesantren program indicators and criteria including: 1) Development of environmentally friendly boarding school policy; 2) Development of environment-based Islamic curriculum; 3) Development of extra curriculum activities based on natural tadabur; and 4) Development and management of suggestions and infrastructure of boarding schools.

These indicators are a benchmark for the identification of EcoPesantren activities. However, physical assessments include identification of energy care, waste/waste management, Pesantren land management, 
healthy culture, biodiversity, sustainability (nonetheless sustainability of environmental programs in the event of a change of leadership) and integration of environmental jurisprudence lessons.

The concept of environmental conservation has three aspects: protection of ecological processes and systems that support human life, the protection of genetic diversity and sustainable use of ecosystems and species. In addition to these three aspects, the concept of environmental management against the $3 \mathrm{R}$ concept of reduction in the source (reduce), reuse and recycle is reflected in the activities of Pesantren educational institutions.

School or educational institution is a strategic land to contribute significantly as well as a place of practice in environmental management. Therefore, Pesantren as an educational institution should at least be as a pilot area of good environmental management although in the form of microscale. One way to protect and improve the environment is to revive the teachings of a religion that have been forgotten and reviewed again to suit the emerging technologies.

Pondok Pesantren commits instilling the excellent values of Islamic teachings that are implemented in various forms of activity and devotion. Pesantren is actively involved in empowering people in various ways to improve morality following the demands of the Qur'an and the prophet. Pesantren not only sees human relationships with their creators, but also teach us about human relationships with other human beings.

Muhammad Muinul Islam states that to improve existing environmental conditions to be healthier and safer, Islamic ethics needs to be implanted at the most important human level, i.e. at the individual level ${ }^{41}$. Pesantren need to remind each that a Muslim should submit himself to the will of Allah SWT and must know the rights of all creatures of Allah SWT to the environmental resources so that the environmental crisis can be inevitable.

The role of Pesantren in the effort of community development and empowerment is one-way Pesantren to get closer to society. This effort can be seen in the more substantial Pesantren activities in which Pesantren are actively involved in the economic activities of the people, the development of technology and information and the most important is its role in environmental

${ }^{41}$ Muhammad Muinul Islam, "Towards a Green Earth: An Islamic Perspective," Asian Affairs, Vol. 26, no. 4 (2004), p. 44-89. 
conservation. Pesantren is currently more open to addressing the problems that exist in the community. The issue of environmental pollution is now not only the responsibility of the government; Pesantren can take the role to finish it. Islamic teachings in Pesantren demand that people be kind to nature. Caring for and protecting the environment is not only the duty of some people but also the duty of all of us, especially those who claim to be Muslims. The existence of normative values in Islamic teachings makes a doctrine that damaging the environment is a sin and is prohibited in religion.

\section{E. Conclusion}

Environmental theology is one solution that can be developed to find answers to current environmental problems. In addition, the concept of EcoPesantren is the basis and good learning with concern for the environment. Furthermore, environmental theology brings Eco-Pesantren to deep ecological-ethical philosophies.

Environmental development efforts can be carried out through a project approach and a motivational approach. This approach to motivation can be done in the pattern of pesantren education. Awareness of environmental balance arising from a basic understanding of problems and implications for ukhrawi welfare and the world can be instilled and developed through education in the environment. Efforts to empower students for environmental health begin by involving students in the process of preservation and management of clean water, clean housing, maintaining cleanliness of public toilets, waste management and broader environmental hygiene participation not only in schools but wider coverage in surrounding communities.

Eco- pesantren teaches religious sciences in the form of learning classical Islamic books or modern books. In addition, Eco-pesantren combine ideology and religious and environmental actions. Pesantren are actively involved in empowering people in various ways to improve morality following the demands of theal-Qur'an and the prophet. The role of pesantren in efforts to empower the community is one direction of the pesantren to be closer to the community. [.] 


\section{REFERENCES}

Adams, John, Jamie Bartram, Jackie Sims, and Yves Chartier. Water, Sanitation and Hygiene Standards for Schools in Low-Cost Settings. World Health Organization, 2009.

Ahmad, Maghfur. "Pendidikan Lingkungan Hidup Dan Masa Depan Ekologi Manusia," 8:57-71, 2010.

Akhter, Mumtaz, Tanveer Iqbal, and Mubashra Khalid. "Islamic Educational Approach to Environment Protection: A Strategic Approach for Secure and Peaceful World." International Journal of Business and Social Science 1, no. 3 (2010).

Alkandri, Kalthoum. "The Transformation and Challenges of Islamic Education in a Globalized." International Education 44, no. 1 (2014), p. 91.

Aquino, Karl, and II Reed. "The Self-Importance of Moral Identity." Journal of Personality and Social Psychology 83, no. 6 (2002), p. 1423.

Bahri, Syamsul. "Pesantren And The Development Of Living Environment: The Study Concept Of Eco-Pesantren In Pondok Pesantren An-Nur Ha Rambigundam Jember." International Journal of Management and Administrative Sciences 5, no. 10 (2018), p. 43-54.

Bailey, Liberty Hyde. “The Holy Earth (1915).” Reprint. New York: New York State College of Agriculture and Life Sciences, 1980.

Baumeister, Roy F. "Understanding the Inner Nature of Low Self-Esteem: Uncertain, Fragile, Protective, and Conflicted." In Self-Esteem, 201-18. Springer, 1993.

Bem, DarylJ. "Self-Perception: An Alternative Interpretation of Cognitive Dissonance Phenomena.” Psychological Review 74, no. 3 (1967), p. 183.

_—_. "Self-Perception Theoryl." In Advances in Experimental Social Psychology, 6:1-62. Elsevier, 1972.

Bodner, Ronit, and Drazen Prelec. "Self-Signaling and Diagnostic Utility in Everyday Decision Making." The Psychology of Economic Decisions 1 (2003), p. 10526.

Cornelissen, Gert, Mario Pandelaere, Luk Warlop, and Siegfried Dewitte. "Positive Cueing: Promoting Sustainable Consumer Behavior by Cueing Common Environmental Behaviors as Environmental.' International Journal of Research in Marketing 25, no. 1 (2008), p. 46-55.

Deci, Edward L, and Richard M Ryan. "The" What" and" Why" of Goal Pursuits: Human Needs and the Self-Determination of Behavior." Psychological Inquiry 11, no. 4 (2000), p. 227-68.

Deuraseh, Nurdeng. Maintaining a Healthy Environment: An Islamic Ethical Approach. Vol. 8, 2009. 
Dunning, David. "Self-image Motives and Consumer Behavior: How Sacrosanct

Self-beliefs Sway Preferences in the Marketplace." Journal of Consumer Psychology 17, no. 4 (2007), p. 237-49.

Foltz, Richard. "Environmentalism in the Muslim World," 2005.

Heberlein, Thomas A. "The Land Ethic Realized: Some Social Psychological Explanations for Changing Environmental Attitudes." Journal of Social Issues 28, no. 4 (1972), p. 79-87.

Hefner, Robert W. Making Modern Muslims: The Politics of Islamic Education in Southeast Asia. University of Hawaii Press, 2009.

Herdiansyah, Herdis, Trisasono Jokopitoyo, and Ahmad Munir. "Environmental Awareness to Realizing Green Islamic Boarding School (Eco-Pesantren) in Indonesia," 30:012017. IOP Publishing, 2016.

Islam, Muhammad Muinul. “Towards a Green Earth: An Islamic Perspective." Asian Affairs 26, no. 4 (2004), p. 44-89.

Kull, Ann. "Gender Awareness in Islamic Education: The Pioneering Case of Indonesia in a Comparison with Pakistan." Studia Islamika 19, no. 3 (2014).

Leiserowitz, Anthony A, Robert W Kates, and Thomas M Parris. "Do Global Attitudes and Behaviors Support Sustainable Development?" Environment: Science and Policy for Sustainable Development 47, no. 9 (2005), p. 22-38.

Leopold, Aldo. A Sand County Almanac: And Sketches Here and There (Outdoor Essays \& Reflections). Oxford University Press, 1989.

Lindenberg, Siegwart, and Linda Steg. "Normative, Gain and Hedonic Goal Frames Guiding Environmental Behavior.” Journal of Social Issues 63, no. 1 (2007), p. 117-37.

Llewellyn, Othman A. "The Basis for a Discipline of Islamic Environmental Law." Islam and Ecology, 2003, p. 185-247.

Lorenzoni, Irene, Sophie Nicholson-Cole, and Lorraine Whitmarsh. "Barriers Perceived to Engaging with Climate Change among the UK Public and Their Policy Implications." Global Environmental Change 17, no. 3-4 (2007), p. 445-59.

Malone, Karen, and Paul Tranter. "'Children's Environmental Learning and the Use, Design and Management of Schoolgrounds." Children Youth and Environments 13, no. 2(2003), p. 87-137.

Mamat, Mohd Nor, and Fattawi Mokhtar. "Environmental Attitude Profile among Muslim Students of Environmental Course in Malaysia." Procedia-Social and Behavioral Sciences 42 (2012), p. 92-99.

Mastuhu. Dinamika Sistem Pendidikan Pesantren: Suatu Kajian Tentang Unsur Dan Nilai Sistem Pendidikan Pesantren. INIS, 1994.

Minteer, Ben A. The Landscape of Reform: Civic Pragmatism and Environmental Thought in America. MIT Press, 2006. 
Nasr, Seyyed Hossein. "Islam and the Environmental Crisis." Islamic Quarterly 34, no. 4(1990), p. 217.

- — - . "Islam and the Problem of Modern Science." Muslim Education Quarterly 5, no. 4 (1988), p. 35-44.

Perveen, Shagufta, and S Farhana Kazmi. "Personality Dynamics of Boarders and Day Scholars Who Belong to Madrassah and Public School." Academic Research International 1, no. 1 (2011), p. 157.

Pihkala, Panu. "Rediscovery of Early Twentieth-Century Ecotheology." Open Theology 2, no. 1 (2016).

Ryan, Richard M, and Edward L Deci. "Self-Determination Theory and the Facilitation of Intrinsic Motivation, Social Development, and Well-Being." American Psychologist 55, no. 1 (2000), p. 68.

Sachdeva, Sonya, Rumen Iliev, and Douglas L Medin. "Sinning Saints and Saintly Sinners: The Paradox of Moral Self-Regulation." Psychological Science 20, no. 4 (2009), p. 523-28.

Schwartz, Shalom H. "Normative Influences on Altruism1." In Advances in Experimental Social Psychology, 10:221-79. Elsevier, 1977.

Schwartz, Shalom H, and Judith A Howard. "A Normative Decision-Making Model of Altruism." Altruism and Helping Behavior, 1981, p. 189-211.

Siregar, Ferry Muhammadsyah. "Religious Leader and Charismatic Leadership in Indonesia: The Role of Kyai in Pesantren in Java." Jurnal Kawistara 3, no. 2 (2013).

Sirry, Mun'im. "The Public Expression of Traditional Islam: The Pesantren and Civil Society in Post-Suharto Indonesia." The Muslim World 100, no. 1 (2010), p. 60-77.

Srimulyani, Eka. "Muslim Women and Education in Indonesia: The Pondok Pesantren Experience." Asia Pacific Journal of Education 27, no. 1 (2007), p. 85-99.

Tan, Charlene. Islamic Education and Indoctrination: The Case in Indonesia. Routledge, 2012.

Taufik, Danny, Jan Willem Bolderdijk, and Linda Steg. "Acting Green Elicits a Literal Warm Glow." Nature Climate Change 5, no. 1 (2015), p. 37.

Taylor, Shelley E, and Jonathon D Brown. "Illusion and Well-Being: A Social Psychological Perspective on Mental Health.” Psychological Bulletin 103, no. 2 (1988), p. 193.

Thøgersen, John. "Recycling and Morality: A Critical Review of the Literature." Environment and Behavior 28, no. 4 (1996), p. 536-58.

Van der Werff, Ellen, Linda Steg, and Kees Keizer. "Follow the Signal: When Past pro-Environmental Actions Signal Who You Are." Journal of Environmental Psychology 40 (2014), p. 273-82. 